\title{
Discount, transparency and announcements effects of equity rights offerings: international evidence
}

\author{
Nils-Christian Bobenhausen ${ }^{1}$ (ID) Astrid Juliane Salzmann ${ }^{2}$
}

Accepted: 4 December 2020 / Published online: 8 January 2021

(c) The Author(s) 2020

\begin{abstract}
Equity rights offerings and their respective announcement effects have been studied extensively in the literature. Our study expands upon these studies and focuses on those announcement effects and the relation between the discount of an equity rights offering and the announcement effect. Previous theoretical and empirical analyses show that firms can signal their quality via the discount in an equity rights offering and demonstrate a negative relation between the discount and the announcement effect. We argue that this link is only relevant in environments where signalling is possible and necessary. These are financial markets with a particularly low level of capital market transparency, i.e. high information asymmetry. We calculate announcement effects for an international sample of equity rights offerings and show that the negative effect of the discount on announcement effects can only be observed in environments with a low capital market transparency. Hence, our study estimates announcement effects across several different countries and is thus among the first to analyse signalling considerations for equity rights offerings in different transparency environments.
\end{abstract}

Keywords Equity rights offering · Transparency $\cdot$ Discount $\cdot$ Event study

JEL Classification $\mathrm{G} 14 \cdot \mathrm{G} 15 \cdot \mathrm{G} 32$

Supplementary Information The online version contains supplementary material available at https:// doi.org/10.1007/s11573-020-01023-8.

Nils-Christian Bobenhausen

nils.bobenhausen@bfw.rwth-aachen.de

Astrid Juliane Salzmann

a.salzmann@ieseg.fr

1 Department of Finance, RWTH Aachen University, Templergraben 64, 52056 Aachen, Germany

2 IESEG School of Management, LEM-CNRS UMR 9221, 3, rue de la Digue, 59000 Lille, France 


\section{Introduction}

Equity offerings provide an important financing source for firms worldwide. In general, there are different ways to issue equity in a seasoned equity offering. The three most popular floatation methods are the free offerings method, private placements and equity rights offerings. Our study focuses on the latter method. Although rights issues are not popular in the US (Singh 1997), they are the main floatation method in many European and Asian countries. For instance, the fraction of rights offerings of all seasoned equity offerings amounts to $85 \%$ in Taiwan, $80 \%$ in New Zealand, $66 \%$ in the UK, 63\% in Italy, 61\% in the Netherlands, 60\% in Norway and 59\% in Finland (Holderness 2018). ${ }^{1}$ Figures reported for the US range around $15 \%$, however (Eckbo and Masulis 1992).

Many empirical studies analyse the announcement effects of equity rights offerings in different countries. ${ }^{2}$ Theoretical and empirical studies show that the discount is a key element for the announcement effects of equity rights issues (e.g. Heinkel and Schwartz 1986; Singh 1997; Slovin et al. 2000; Kabir and Roosenboom 2003; Balachandran et al. 2012). The discount is the difference between the stock price prior to the announcement and the subscription price in relation to the stock price prior to the announcement of an equity rights issue. In their signalling model, Heinkel and Schwartz (1986) show that firms can signal their quality to the uninformed shareholders via the discount. High quality firms should choose lower discounts to signal their quality.

Even though the theoretical literature mostly postulates negative announcement effects for equity rights issues (Myers and Majluf 1984; Heinkel and Schwartz 1986), several empirical studies still document positive announcement effects in several countries. Hence, country-specific factors such as the legal environment seem to matter for explaining announcement effects of equity rights offerings. We use an international dataset to examine these cross-country differences and expand the literature on equity rights offerings to an international context. In our study, we conjecture that the discount is only relevant in countries with a ceteris paribus higher information asymmetry between (uninformed) shareholders and management, as signalling is necessary and possible in those environments. Thus, the discount should be an essential factor to explain announcement effects of equity rights offerings in those countries. We employ the level of capital market transparency as a proxy for information asymmetry on the country level. As institutional factors have been largely documented to affect financing decisions (Fan et al. 2012), they might also impact their announcement effects.

We use an event study methodology to calculate announcement effects of equity rights issues. We then split the sample into firms operating in high and low levels of capital market transparency to assess whether the discount impacts the announcement effects under different information asymmetry environments. Analysing the

\footnotetext{
1 In Germany, the number of non-rights issues is also negligible (Gebhardt et al. 2001).

2 Announcement effects measure the difference between the actual and the expected returns, i.e. the returns we would expect without any announcement of an equity offering.
} 
announcement effect of 1,071 equity rights offerings from 44 countries, we find that the negative impact of the discount of an equity rights offering on the announcement effect only persists in low transparency, i.e. high information asymmetry, environments.

Generally, firms can issue their shares below the market price (i.e. at a discount) in free offerings. Our study focuses on rights offerings, as the discount is especially relevant for this floatation method. For equity rights offerings, there is usually a large time span between the announcement of the offer and the closure of the offer or the expiry date of subscription rights. For instance, this time span amounts to 32 trading days on average in Australia (Balachandran et al. 2012), 13 trading days in the US (Singh 1997), and at least 10 trading days in Germany. Hence, since the rights trading period is typically long, the discount is of particular relevance in equity rights offerings. If the share price falls below the subscription price during this period, the offer might not obtain sufficient financial resources and will eventually fail. Due to this long trading period, it is more difficult for low quality firms to mimic high quality ones, as the mimicry might unravel during this period.

Our study contributes to the existing literature in two ways. On the one side, to the best of our knowledge, we are the first to analyse the impact of the discount of equity rights issues on the announcement effects using an international sample across diverging capital market transparency environments. On the other side, we calculate announcement effects for different countries and can therefore compare those effects across countries using the same method and time period, which ensures comparability. The varying announcement effects of equity rights issues across countries have not been studied comprehensively in the previous literature. We highlight that the discount only influences announcement effects in low transparency environments, which might shed light on the unresolved country puzzle.

This paper is structured as followed. In Sect. 2, we review the theoretical and empirical literature. We describe our data in Sect. 3. Section 4 presents our results. Section 5 concludes.

\section{Signalling and information asymmetry}

Modigliani and Miller (1958) were among the first to analyse the effect of financing decisions on firm value. On a perfect capital market, the choice between equity and debt financing has no influence on firm value and shareholder wealth. However, if the assumption of a perfect capital market is relaxed, this finding does not hold anymore. Myers and Majluf (1984) presume a certain degree of information asymmetry about the firm value between the better-informed management and the worse-informed shareholders. Shareholders can infer the firm value from financing decisions, and the decision between an equity or debt offering serves as a signal for shareholders. The analysis demonstrates that the announcement of an equity offering signals that the firm is currently overvalued. Hence, the announcement of an equity offering signals poor firm quality and thus leads to negative announcement effects, if a certain degree of information asymmetry between the better-informed management and the worse-informed shareholders is present. This result coincides 
with the market-timing-theory developed by Baker and Wurgler (2002). They also predict that the announcement of an equity offering will lead to negative announcement effects, because firms will issue equity when their market valuation is ceteris paribus higher, in order to exploit the (over-) valuation. As the announcement of an equity offering incentivizes shareholders to re-evaluate the firm, certain shareholders might detect the overvaluation and thus sell their shares, which leads to a declining share price. However, if the market becomes more transparent, the information asymmetry is reduced. The negative announcement effect should hence become less negative, as shareholders can estimate the true firm value more easily. In addition, a potential overvaluation will be detected more easily. This might incentivize firms to time their equity offerings in periods of lower overvaluation, which reduces the negative announcement effect. This reasoning indicates that information asymmetry in an important factor for equity offerings.

Several studies build on the Myers and Majluf (1984) signalling framework and argue that (uninformed) shareholders can infer the firm value from the announcement of an equity issue and its determinants. For instance, Heinkel and Schwartz (1986) show that firms can signal their quality in an equity rights issue via the discount. They demonstrate in a theoretical model that high quality firms can signal their quality via the implementation of smaller discounts and hence higher subscription prices. Consequently, they generate higher actual stock returns, so that the announcement effect of firms with smaller discounts is less negative than the announcement effect of firms with larger discounts. This leads to a negative expected relation between discounts and announcement effects. The discount and the accompanying signalling considerations are hence substantial components of an equity rights issue.

Heinkel and Schwartz (1986) show theoretically that high quality firms can signal their quality by setting smaller discounts in an equity offering and thus choosing higher offer prices. We suppose that the level of information asymmetry might play a crucial role in assessing whether signalling via the discount is possible and necessary. In markets with a particularly low level of information asymmetry, signalling might not be relevant, as market participants can estimate the true firm value more reliably compared to markets with higher information asymmetry. This leads to the hypothesis for our study:

The negative impact of the discount on announcement effects in equity rights issues is only relevant in environments with ceteris paribus higher information asymmetry.

To the best of our knowledge, no previous study evaluates the effect of the discount in different information asymmetry setting on the announcement effect for equity rights offerings. A related study by Francis et al. (2010) analyses the importance of signalling prior to an IPO using an international sample. The authors show that signalling is important in countries with segmented financial markets, while signalling prior to an IPO is not relevant in countries with fully integrated financial markets. Countries with segmented financial markets should also constitute those with higher information asymmetry, as their financial markets might be less developed. Building on these results, we expect similar results for equity rights offerings, 
namely that the discount as a signalling instrument should only be relevant in environments with high information asymmetry.

Holderness and Pontiff (2016) demonstrate a further link between discounts and announcement effects via the wealth transfer of an equity rights offering between participating and non-participating shareholders. This wealth transfer occurs if shareholders let their rights expire. If the offer is priced at a discount, shareholders leave money on the table by letting their rights expire. The authors show that higher wealth transfer leads to lower announcement effects empirically, and that the discount affects the wealth transfer in two opposing ways. First, higher discounts should lead to a higher wealth transfer, as shareholders not exercising their rights leave more money on the table. On the other hand, higher discounts lead to higher participation rates, which decreases the wealth transfer as fewer shareholders let their rights expire. However, as the empirical effect of the wealth transfer on announcement effects is negative, the first effects seems to dominate the latter one. Consequently, the discount can negatively affect announcement effects at least via two channels. Our analysis focuses only on the direct channel as we do not have appropriate data to estimate and examine shareholder participation. We leave the indirect channel through the wealth transfer for future analyses.

\section{Sample selection and variables description}

In this section, we describe our dataset and its origin, define the construction of our variables and present some descriptive statistics.

\subsection{Sample description}

We obtain an international database of 6458 equity rights offerings. We lose observations due to several data requirements. First, for 587 observations, we do not have sufficient stock data to calculate cumulated abnormal returns. Furthermore, we drop 11 observations with a cumulated abnormal return of lower than $-100 \%$ and 67 observations with a cumulated abnormal return of higher than $100 \%$. $^{3}$ This leaves 5793 observations from 86 countries between 1996 and 2011 for our event study. Unfortunately, we cannot use all of those observations for our following regressions due to some data constraints. For our regressions, we drop all observations with a discount smaller than zero. A negative discount indicates a potential measurement error, since negative discounts in an equity rights offering seem implausible. In line with our event study, we continue to exclude all observations with $C A R$ smaller than $-100 \%$. We also delete equity rights offerings for which we do not have sufficient

\footnotetext{
3 We exclude those offerings in order to avoid a distortion of our event study results due to extreme values. However, we again include observations with CAR $>100 \%$ in all our regressions. As we winsorize the variables for our regression approach, extreme values only have a limited potential for distortion here. We would like to thank an anonymous referee for this suggestion.
} 
Table 1 Dataset breakdown

\begin{tabular}{ll}
\hline 6458 & Rights offerings \\
-587 & Missing CAR \\
$=5871$ & \\
-67 & CAR $>100 \%$ \\
$=5804$ & \\
-11 & CAR $<-100 \%$ \\
$=5793$ & Event-Study observations \\
+67 & CAR $>100 \%$ \\
$=5860$ & \\
-1374 & Discount $<0$ \\
$=4486$ & \\
-3415 & Missing firm-level controls \\
$=1071$ & Regression observations \\
\hline
\end{tabular}

This table breaks down our dataset construction. Starting with 6458 equity rights offerings, we lose several observations due to missing data or other exclusions

data for all control variables. This reduces our dataset substantially and leaves 1071 observations for our regressions. Table 1 breaks down our dataset in detail.

We obtain data on announcement dates and firm-specific variables from Capital IQ. We add country-specific data from various external sources, such as the World Bank, the Global Competitiveness Report, or established papers (Doidge et al. 2007; Djankov et al. 2008). We assign firms to countries via the location of the headquarter. We detail the sources for these country-level variables in Table 3.

\subsection{Cumulated abnormal returns}

To calculate announcement effects, we follow MacKinlay (1997) and employ a basic event study methodology. ${ }^{4}$ For the estimation of abnormal returns, we use a market model with an estimation window of 84 trading days, starting 89 trading days and ending 6 trading days prior to the announcement of the equity rights offering. For each country, we use the return of a local stock market index as the market return. ${ }^{5}$ Our event window starts five trading days prior to the announcement of the equity rights offering and ends five trading days after it. Thus, we calculate cumulated abnormal returns $(C A R)$ for each offering over these 11 days as the announcement effect. After the calculation of $C A R$, we test the statistical significance of $C A R$

\footnotetext{
${ }^{4}$ We define the announcement effect as the cumulated abnormal return, which we calculate as sum of all abnormal returns over our event window. We define abnormal returns as the difference between the actual return (in which the announcement is incorporated) and the expected return (without the announcement) on a certain day. Hence, positive announcement effects show that (cumulated) actual stock returns are higher than the (cumulated) expected returns. Negative announcement effects occur if (cumulated) actual stock returns are lower than the (cumulated) expected ones.

5 We present an overview of the local indexes employed for each country in our online appendix.
} 
following MacKinlay (1997). A detailed description of our event study methodology can be found in the online Appendix.

Table 2 presents the results of our event study on announcement effects of equity rights issues for 86 countries. It shows that there is no consistent announcement effect across all countries, which is in line with the previous literature. In total, we measure on average negative effects for 59 countries, while we observe on average positive effects in 27 countries.

Though it is beyond the scope of our study to completely uncover the reasons behind these differences, we set out to examine whether the discount has different effects across different countries and transparency environments. The differences in announcement effects worldwide indicate that country-specific factors exist which might help to solve the country puzzle.

\subsection{Discount}

Our main independent variable is the discount of an equity rights offerings (Discount). We calculate the discount of an equity rights offering as the difference between the stock price two days prior to the announcement and the subscription price in relation to the stock price two days prior to the announcement.

$$
\text { Discount }=\frac{\text { Stock price }_{\mathrm{t}-2}-\text { Subscription price }}{\text { Stock price }_{\mathrm{t}-2}}
$$

This definition is in line with previous studies analysing announcement effects of equity rights offerings (e.g. Balachandran et al. 2012; as well as Singh 1997). Higher subscription prices lead to lower discounts and vice versa.

\subsection{Transparency}

The key element in our study is the assessment of information asymmetry. Our study focuses on the prevailing degree of financial market transparency in a certain country. In environments with higher financial market transparency, firms disclose more information, which makes the assessment of the firm value easier and more accurate. This should lead to lower information asymmetry between shareholders and management and vice versa. We employ two alternative country-level variables as measures for market transparency.

As a first proxy for market transparency in a certain country, we employ a variable from the Global Competitiveness Report. Financial Market Development (Market Development) covers transparency, investor protection, and regulation in the banking sector. Higher values indicate that the financial market is sophisticated, well governed and regulated and has a sound banking system. Hence, such countries should face a higher financial transparency. As a second proxy, we follow Doidge et al. (2007) and use the Standard and Poor's governance rating (Governance Rating). This rating covers developed as well as less developed countries and derives a score for each country. Higher scores indicate that firms in these countries 
Table 2 Event study results

\begin{tabular}{|c|c|c|c|c|c|}
\hline Country & $\mathrm{N}$ & CAR $(\%)$ & Country & $\mathrm{N}$ & CAR $(\%)$ \\
\hline Argentina & 2 & 12.41 & Lithuania & 7 & -5.09 \\
\hline Australia & 1452 & $-1.45^{* *}$ & Luxembourg & 6 & 9.45 \\
\hline Austria & 48 & -0.4 & Malaysia & 138 & -1.92 \\
\hline Bahrain & 8 & $12.55 * *$ & Malta & 1 & -46.38 \\
\hline Bangladesh & 17 & 1.11 & Mexico & 4 & -4.21 \\
\hline Barbados & 1 & -5.08 & Morocco & 2 & 0.68 \\
\hline Belgium & 21 & -3.65 & Netherlands & 25 & -2.4 \\
\hline Bermuda & 15 & 5.74 & New Zealand & 56 & $-5.86^{* *}$ \\
\hline Brazil & 10 & -5.68 & Nigeria & 23 & -0.1 \\
\hline British Virgin Islands & 1 & -1.12 & Norway & 101 & -3.8 \\
\hline Bulgaria & 14 & -2.51 & Oman & 9 & 4.25 \\
\hline Canada & 90 & -4.49 & Pakistan & 57 & -1.88 \\
\hline Cayman Islands & 3 & -1.12 & Papua New Guinea & 1 & -4.82 \\
\hline Channel Islands & 12 & -1.27 & Philippines & 47 & -1.42 \\
\hline Chile & 11 & 2.88 & Poland & 40 & -0.22 \\
\hline China & 96 & 1.54 & Portugal & 16 & 1.71 \\
\hline Colombia & 1 & -11.48 & Qatar & 10 & 2.04 \\
\hline Croatia & 2 & -3.3 & Romania & 16 & -1.48 \\
\hline Cyprus & 12 & 0.58 & Russia & 3 & -9.88 \\
\hline Denmark & 41 & $-6.76^{*}$ & Saudi Arabia & 8 & 3.93 \\
\hline Dominican Republic & 1 & -1.63 & Serbia & 2 & -0.97 \\
\hline Egypt & 68 & -1.75 & Singapore & 155 & -2.97 \\
\hline Estonia & 1 & 8.15 & Slovakia & 1 & -2.78 \\
\hline Finland & 28 & 1.86 & Slovenia & 1 & -0.93 \\
\hline France & 178 & -1.05 & South Africa & 54 & 0.08 \\
\hline Germany & 221 & 0.81 & South Korea & 304 & $-12.93 * * *$ \\
\hline Ghana & 4 & 0.21 & Spain & 51 & 0.61 \\
\hline Greece & 53 & $-4.92 * * *$ & Sri Lanka & 54 & 2.18 \\
\hline Hong Kong & 243 & $-8.31 * * *$ & Sweden & 360 & $-2.95^{* *}$ \\
\hline Iceland & 1 & -1.89 & Switzerland & 57 & $3.83 * *$ \\
\hline India & 200 & $-1.61 *$ & Taiwan & 118 & 0.25 \\
\hline Indonesia & 68 & $-2.89 *$ & Tanzania & 3 & -7.69 \\
\hline Ireland & 17 & -0.7 & Thailand & 82 & $-4.36^{* *}$ \\
\hline Israel & 40 & -4.58 & Togo & 1 & -47.19 \\
\hline Italy & 100 & -0.55 & Tunisia & 3 & -2.21 \\
\hline Jamaica & 1 & 25.13 & Turkey & 4 & -7.3 \\
\hline Japan & 6 & -13.36 & Ukraine & 2 & 5.42 \\
\hline Jordan & 2 & -6.89 & United Arab Emirates & 3 & -4.32 \\
\hline Kazakhstan & 3 & -5.36 & United Kingdom & 313 & $-4.08 * * *$ \\
\hline Kenya & 11 & -1.52 & United States & 352 & -0.42 \\
\hline Kuwait & 10 & 0.61 & Vietnam & 178 & $-2.4 * *$ \\
\hline Latvia & 4 & -3.56 & Zambia & 2 & -7.64 \\
\hline
\end{tabular}


Table 2 (continued)

\begin{tabular}{|c|c|c|c|c|c|}
\hline Country & $\mathrm{N}$ & CAR (\%) & Country & $\mathrm{N}$ & CAR (\%) \\
\hline \multirow[t]{2}{*}{ Lebanon } & 3 & 3.93 & Zimbabwe & 3 & 33.87 \\
\hline & & & Worldwide & 5793 & $-2.47 * * *$ \\
\hline
\end{tabular}

This table presents the cumulated abnormal returns across countries from our event study. Section 3 describes the methodology of our event study. We exclude observations with CAR $>100 \%$ and CAR $<-100 \%$ from our event study

$* * *$ Denotes significance at the $1 \%$-level, **denotes significance at the $5 \%$-level and $*$ denotes significance at the $10 \%$ - level

disclose more items in their annual reports and regulatory filings, which should lead to higher transparency.

\subsection{Controls}

We use several control variables in all regressions. As a first step, we follow Campello and Graham (2013) and decompose the market-to-book-ratio (MTBR) into two parts: The growth opportunities (Growth) of a firm and the current overvaluation $(O V) .{ }^{6}$ In addition to these variables, we employ several other control variables on firm level. Debt Repayment takes on the value of one if the firm announces that it uses the offer proceeds to repay debt, and zero otherwise. New Investment takes on the value of one if the firms uses the issue proceeds for new investment projects, and zero otherwise. Underwritten is a dummy variable which takes on the value of one if the offer is underwritten, and zero otherwise. Furthermore, we define Leverage as total debt in relation to total assets. We calculate Relative Size as gross offering amount in relation to market capitalization to control for potential offer size effects. Concentration measures the percentage of shares not in free float, while Analysts describes the natural logarithm of the number of total analysts following the firm. Moreover, we define Return STD as the standard deviation of stock returns 90 days prior to the announcement, and Return LTM describes the last-twelve-month stock return in relation to the index performance. ${ }^{7}$

Besides those firm and offer characteristics, we additionally control in each regression for potential effects on the country level. Civil takes on the value of one if the legal system is based on civil law in that specific country. Investor Protection measures the strength of investor protection in a certain country, while Legal Rights describes the protection of borrowers and lenders rights on the country level. Both variables come from the Doing Business Report. As a further country-specific variable, we use the Anti-Self-Dealing-index from Djankov et al. (2008). GDP per capita captures the gross domestic product in 10,000 US-Dollar of the specific country.

\footnotetext{
${ }^{6}$ We present the detailed procedure for the decomposition of MTBR into $O V$ and Growth in the online appendix.

7 Bobenhausen et al. (2020) show that the volatility plays a key role in explaining discounts in equity rights offerings.
} 
These control variables on the country level are time-invariant, as country-specific factors change, if at all, slowly.

Table 3 summarizes all variable definitions.

\subsection{Descriptive statistics}

Table 3 reveals some interesting aspects about our dataset. The median of Discount amounts to $30.52 \%$. The median of $R O A$ is $-2.79 \%$, which already indicates that firms announcing a rights offering might on average suffer from poor firm quality, which is in line with the prediction by Myers and Majluf (1984). Furthermore, $45.29 \%$ of all offerings are underwritten. The median of Relative Size amounts to $26.16 \%$, which shows that the offerings in our sample have a quite high offering size.

To further characterize our dataset, we calculate the correlation coefficients for all variables based on the data included in our main regression. Table 4 presents the correlation matrix. Some interesting findings emerge. At a first glance, there seems to be no direct connection between our proxies for capital market transparency Market Development or Governance Rating and CAR. Nevertheless, our following analyses demonstrate that they are important moderators for the effect of the discount on the announcement effects as presumed in our hypothesis. Furthermore, higher growth opportunities relate negatively to announcement effects, while higher return-on-assets leads to higher announcement effects, indicating that firms with a higher quality should generate higher announcement effects. Additionally, New Investment is negatively correlated with $C A R$, which suggests that firms using their offer proceeds for new investment projects might incur lower announcement effects. According to Heinkel and Schwartz (1986), the decision to underwrite an offer can itself function as a signal of firm quality, similarly to the discount. They conclude that firms using underwritten rights offerings are ceteris paribus of a higher quality than firms using non-underwritten rights offerings. Yet, the negative correlation of Underwritten and CAR in this preliminary analysis contrasts this theory. We review this issue in detail in Sect. 5. Moreover, Analysts, Return STD as well as Civil all appear to have a positive influence on announcement effects of equity rights offerings.

\section{Empirical analysis}

In this section, we demonstrate our main results and test our hypothesis. Starting with the description of our regression methodology, we present our main regressions and supporting analyses afterwards. We conclude the section with some additional tests to demonstrate the robustness of our results.

\subsection{Regression methodology}

To examine our hypothesis, we employ an OLS regression as our main approach. We define the cumulated abnormal return in the 11 day event window $[-5 ;+5]$ 


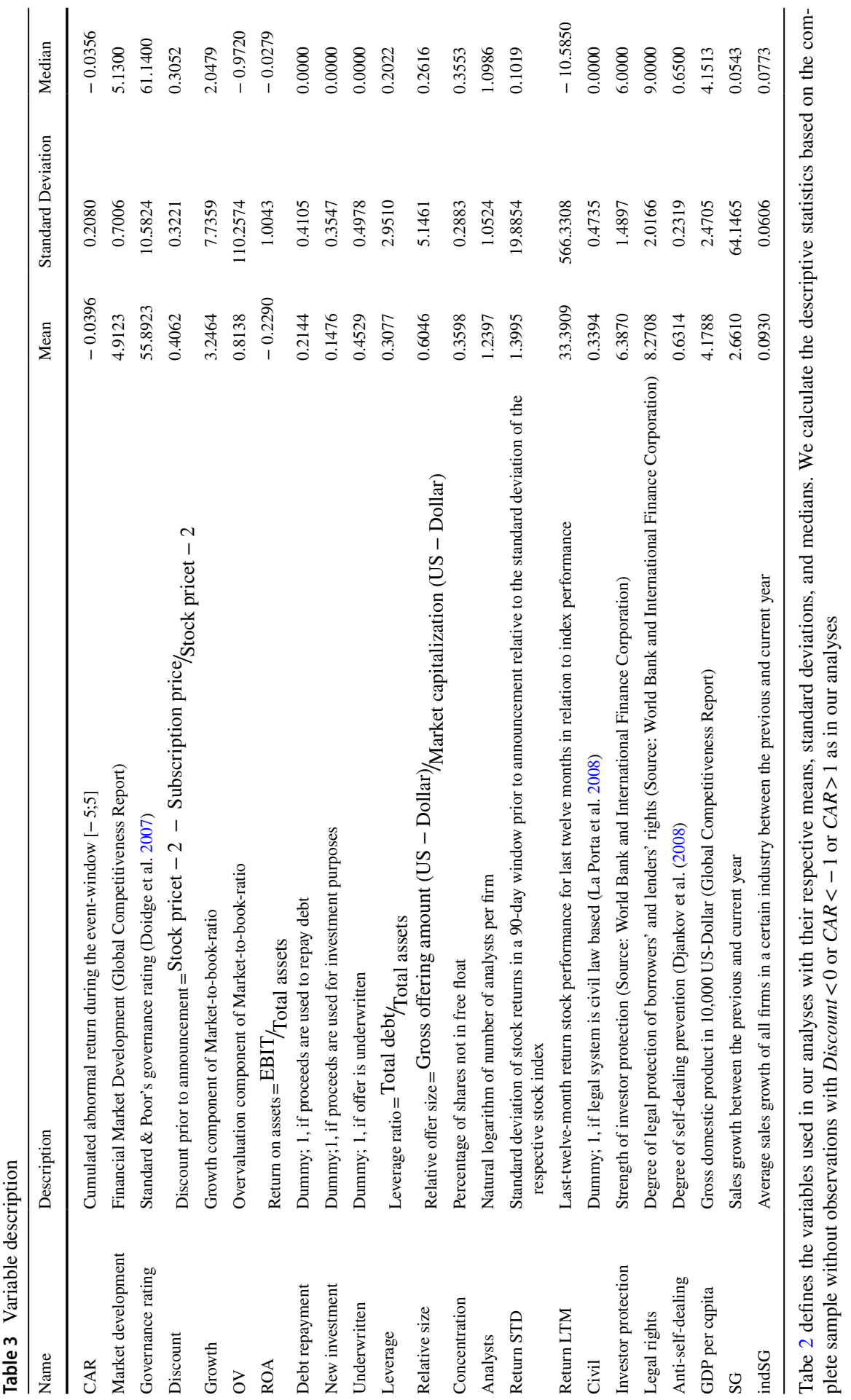


$(C A R)$, denoting the announcement effect of the offering, as our dependent variable in all regressions. We winsorize all variables at the $1 \%$-level and use robust standard errors clustered on industry level.

We perform sample splits using the median value of our two proxies for information asymmetry as a cut-off point. We split our sample in firms with high (larger than the median) and low (smaller or equal to the median) financial market transparency via the two variables introduced above. For each subsample, we conduct regressions according to the following equation:

$$
\begin{aligned}
& \mathrm{CAR}_{\mathrm{i}}=\beta_{0}+\beta_{1} \times \text { Discount }_{\mathrm{i}}+\beta_{2} \times \text { Growth }_{\mathrm{i}}+\beta_{3} \times \mathrm{OV}_{\mathrm{i}}+\beta_{4} \times \mathrm{ROA}_{\mathrm{i},}+\beta_{5} \times \text { Debt Repayment }_{\mathrm{i}, \mathrm{t}}+ \\
& \beta_{6} \times \text { New Investment }{ }_{i}+\beta_{7} \times \text { Underwritten }_{i}+\beta_{8} \times \text { Relative Size }_{i}+\beta_{9} \times \text { Concentration }_{i}+
\end{aligned}
$$

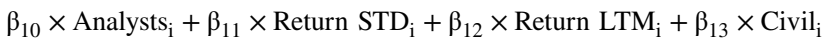

$$
\begin{aligned}
& \beta_{14} \times \text { Investor Protection }_{\mathrm{i}}+\beta_{15} \times \text { Legal Rights }_{\mathrm{i}}+\beta_{16} \times \text { Anti }- \text { Self }- \text { Dealing }_{\mathrm{i}}+ \\
& \beta_{17} \times \text { GDP per capita }{ }_{\mathrm{i}}+\varepsilon_{\mathrm{i}}
\end{aligned}
$$

Additionally, we include year and industry fixed effects in all regressions. We define 11 industries along the SIC Division Structure (https://www.osha.gov/pls/ imis/sic_manual.html).

\subsection{Main regressions}

Table 5 depicts our main regression results regarding our hypothesis. In this analysis, we split our sample into firms with high and low financial market transparency and run the previously described regression for both subsamples. We classify an observation as a firm with a high transparency if its transparency score is larger than the median of all observations in both samples. ${ }^{8}$

The results support our hypothesis and show that the negative effect of the discount on announcement effects persist only in environments with a low financial market transparency and thus higher information asymmetry. The negative coefficient of Discount is only significant in low transparency environments. This indicates that signalling via the discount in an equity rights offering appears to be only relevant if the financial market transparency is particularly low. Our results hence support that the findings from Francis et al. (2010) for initial public offerings also hold for equity rights offerings. ${ }^{9}$

Some further interesting findings emerge from these regressions. The coefficient of $O V$ is negative. This shows that overvalued firms generate ceteris paribus lower announcement effects, which is in line with Baker and Wurgler (2002). However, the coefficient of $O V$ only loads significantly in high transparency environments, indicating that shareholders might detect the overvaluation only if the capital market transparency is sufficiently high. Thus, overvalued firms only experience significant

\footnotetext{
8 We present a detailed list of countries included in both subsamples in the online Appendix.

9 These results hold if we only include offerings with a significant cumulated abnormal return in our regression.
} 


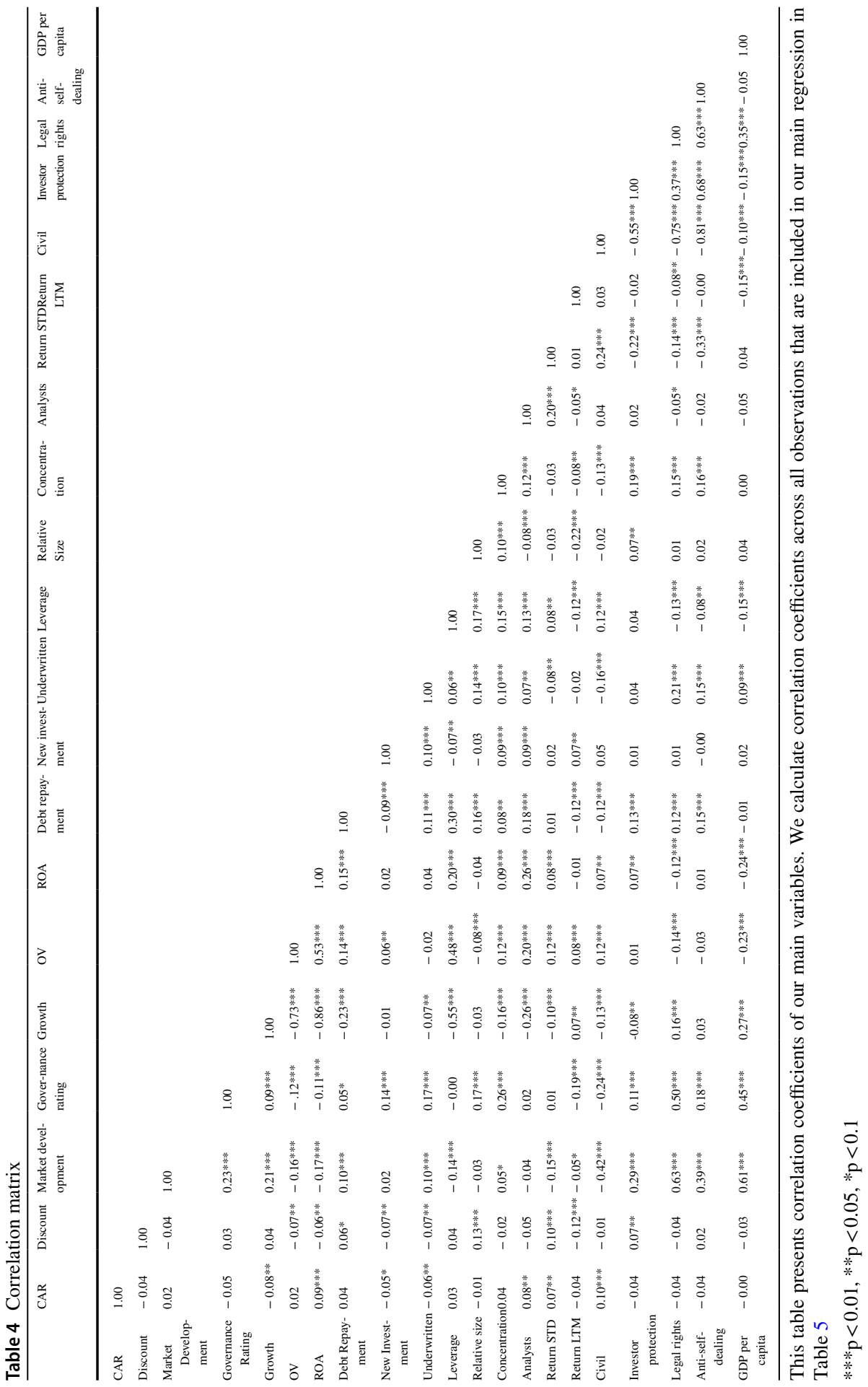


Table 5 Main regression results

\begin{tabular}{|c|c|c|c|c|}
\hline Variables & $\begin{array}{l}\text { (1) High Market } \\
\text { Development }\end{array}$ & $\begin{array}{l}\text { (2) Low Market } \\
\text { Development }\end{array}$ & $\begin{array}{l}\text { (3) High Govern- } \\
\text { ance Rating }\end{array}$ & $\begin{array}{l}\text { (4) Low Gov- } \\
\text { ernance Rating }\end{array}$ \\
\hline Discount & $\begin{array}{l}-0.016 \\
(0.033)\end{array}$ & $\begin{array}{l}-0.084 * * * \\
(0.025)\end{array}$ & $\begin{array}{l}-0.048 \\
(0.034)\end{array}$ & $\begin{array}{l}-0.061^{* * *} \\
(0.025)\end{array}$ \\
\hline Growth & $\begin{array}{l}-0.004 \\
(0.020)\end{array}$ & $\begin{array}{l}0.002 \\
(0.014)\end{array}$ & $\begin{array}{l}-0.001 \\
(0.014)\end{array}$ & $\begin{array}{l}-0.007 \\
(0.030)\end{array}$ \\
\hline $\mathrm{OV}$ & $\begin{array}{l}-0.006^{*} \\
(0.003)\end{array}$ & $\begin{array}{l}-0.008 \\
(0.005)\end{array}$ & $\begin{array}{l}-0.006^{* *} \\
(0.002)\end{array}$ & $\begin{array}{l}-0.008 \\
(0.006)\end{array}$ \\
\hline ROA & $\begin{array}{l}0.020 \\
(0.150)\end{array}$ & $\begin{array}{l}0.074 \\
(0.123)\end{array}$ & $\begin{array}{l}0.054 \\
(0.125)\end{array}$ & $\begin{array}{l}0.046 \\
(0.186)\end{array}$ \\
\hline Debt repayment & $\begin{array}{l}0.004 \\
(0.012)\end{array}$ & $\begin{array}{l}0.017 \\
(0.010)\end{array}$ & $\begin{array}{l}-0.001 \\
(0.022)\end{array}$ & $\begin{array}{l}0.022^{*} \\
(0.012)\end{array}$ \\
\hline New investment & $\begin{array}{l}-0.009 \\
(0.013)\end{array}$ & $\begin{array}{l}-0.033^{*} \\
(0.015)\end{array}$ & $\begin{array}{l}-0.023 \\
(0.021)\end{array}$ & $\begin{array}{l}-0.019 \\
(0.012)\end{array}$ \\
\hline Underwritten & $\begin{array}{l}-0.039 \\
(0.027)\end{array}$ & $\begin{array}{l}-0.027 \\
(0.018)\end{array}$ & $\begin{array}{l}-0.041 * \\
(0.020)\end{array}$ & $\begin{array}{l}-0.014 \\
(0.014)\end{array}$ \\
\hline Leverage & $\begin{array}{l}0.016 \\
(0.110)\end{array}$ & $\begin{array}{l}0.034 \\
(0.059)\end{array}$ & $\begin{array}{l}0.063 \\
(0.091)\end{array}$ & $\begin{array}{l}-0.006 \\
(0.126)\end{array}$ \\
\hline Relative size & $\begin{array}{l}0.015 \\
(0.026)\end{array}$ & $\begin{array}{l}0.037 \\
(0.049)\end{array}$ & $\begin{array}{l}0.049 * \\
(0.022)\end{array}$ & $\begin{array}{l}-0.011 \\
(0.047)\end{array}$ \\
\hline Concentration & $\begin{array}{l}0.107 * \\
(0.052)\end{array}$ & $\begin{array}{l}-0.014 \\
(0.046)\end{array}$ & $\begin{array}{l}0.060 \\
(0.046)\end{array}$ & $\begin{array}{l}-0.004 \\
(0.051)\end{array}$ \\
\hline Analysts & $\begin{array}{l}0.019 * * \\
(0.008)\end{array}$ & $\begin{array}{l}0.003 \\
(0.012)\end{array}$ & $\begin{array}{l}0.004 \\
(0.008)\end{array}$ & $\begin{array}{l}0.011 \\
(0.011)\end{array}$ \\
\hline Return STD & $\begin{array}{l}0.018 * * \\
(0.007)\end{array}$ & $\begin{array}{l}0.004 \\
(0.003)\end{array}$ & $\begin{array}{l}0.012 \\
(0.013)\end{array}$ & $\begin{array}{l}0.006 \\
(0.005)\end{array}$ \\
\hline Return LTM & $\begin{array}{l}-0.000 \\
(0.000)\end{array}$ & $\begin{array}{l}-0.000^{* * * *} \\
(0.000)\end{array}$ & $\begin{array}{l}-0.000 \\
(0.000)\end{array}$ & $\begin{array}{l}-0.000^{*} \\
(0.000)\end{array}$ \\
\hline Civil & $\begin{array}{l}0.082 \\
(0.073)\end{array}$ & $\begin{array}{l}0.118 * * * \\
(0.028)\end{array}$ & $\begin{array}{l}-0.127 \\
(0.196)\end{array}$ & $\begin{array}{l}0.117 * * * \\
(0.024)\end{array}$ \\
\hline Investor protection & $\begin{array}{l}0.005 \\
(0.007)\end{array}$ & $\begin{array}{l}-0.009 \\
(0.008)\end{array}$ & $\begin{array}{l}0.001 \\
(0.017)\end{array}$ & $\begin{array}{l}-0.009 * \\
(0.004)\end{array}$ \\
\hline Legal rights & $\begin{array}{l}0.018 \\
(0.014)\end{array}$ & $\begin{array}{l}0.011 * * \\
(0.005)\end{array}$ & $\begin{array}{l}0.042 \\
(0.081)\end{array}$ & $\begin{array}{l}0.009 \\
(0.006)\end{array}$ \\
\hline Anti-self-dealing & $\begin{array}{l}0.083 \\
(0.155)\end{array}$ & $\begin{array}{l}0.129 * * * \\
(0.027)\end{array}$ & $\begin{array}{l}-0.488 \\
(0.703)\end{array}$ & $\begin{array}{l}0.217 \text { *** } \\
(0.036)\end{array}$ \\
\hline GDP per capita & $\begin{array}{l}0.005 \\
(0.008)\end{array}$ & $\begin{array}{l}-0.015^{*} \\
(0.007)\end{array}$ & $\begin{array}{l}-0.017 \\
(0.061)\end{array}$ & $\begin{array}{l}-0.002 \\
(0.003)\end{array}$ \\
\hline Constant & $\begin{array}{l}-0.644^{* *} \\
(0.217)\end{array}$ & $\begin{array}{l}-0.179^{* *} \\
(0.075)\end{array}$ & $\begin{array}{l}-0.109 \\
(0.274)\end{array}$ & $\begin{array}{l}-0.406^{* * *} \\
(0.164)\end{array}$ \\
\hline Observations & 499 & 572 & 522 & 462 \\
\hline Adjusted R-squared & 0.040 & 0.039 & 0.026 & 0.067 \\
\hline Prob $>F$ & 0.0000 & 0.0000 & 0.0001 & 0.0000 \\
\hline
\end{tabular}


Table 5 (continued)

This table presents regression results for our OLS regression with $C A R$ as the dependent variable. In Model 1 and 2, we split the sample into firm with high (larger than median) and low (smaller or equal to median) values of Market Development. In Model 3 and 4, we split the sample into firm with high (larger than median) and low (smaller or equal to median) values of Governance Rating. Variable definitions can be found in Table 3. Each regression includes year and industry fixed effects. We present robust standard errors clustered on the industry level in parentheses $(* * * \mathrm{p}<0.01, * * \mathrm{p}<0.05, * \mathrm{p}<0.1)$

negative announcement effects in those environments. Furthermore, $R O A$ relates positively to the announcement effects in all regressions. Even though the coefficient is not statistically significant, its sign indicates that a higher return-on-assets induces ceteris paribus higher announcement effects. With $R O A$ as a proxy for firm quality, this result suggests that higher firm quality tends to lead to higher announcement effects. In addition, all regression results hint at a negative impact of Underwritten on announcement effects. Hence, the decision to underwrite an equity rights offering seems to generate ceteris paribus lower announcement effects. Although the coefficient of Underwritten is only significant in one model, its sign is negative across all regressions. This result is in contrast to the theoretical model of Heinkel and Schwartz (1986), which predicts a positive effect for underwritten offerings. We trace this difference back to the fact that we use an international dataset of rights offerings. As a certain floatation method might be especially popular in a certain country (see, e.g., Bøhren et al. 1997; or Eckbo and Masulis 1992), the coefficient of Underwritten might result from particular country-specific effects.

Our results are also important in terms of economic significance. For instance, in countries with low values of Market Development, a one percentage point increase in the discount leads to a ceteris paribus 0.00084 percentage points lower announcement effect or cumulated abnormal return. Considering a mean announcement effect of $-2.94 \%$ (mean announcement effect calculated across all observations included in the subsample of low Market Development, Model 2, Table 5), a one percentage point increase of the discount in environments with low values of Market Development leads to a predicted announcement effect of $-3.02 \%$ and thus a decrease of $2.72 \%$ in regard to the mean value. Similar results can be found when using the other proxy.

\subsection{Additional analyses}

One might object that other factors exist besides the discount, which matter for announcement effects in terms of signalling considerations. In a first additional test we hence analyse whether the negative influence of the discount on announcement effects persists across the whole sample of equity rights offerings. Model 1 from Table 6 presents our main regression and corresponding results. The coefficient of Discount is significantly negative for the regressions using the whole sample, which highlights the importance of the discount as a signalling instrument.

Additionally, we test whether certain firm and offer characteristics might influence the relevance of the discount as a signalling instrument. For instance, the relevance of the discount might depend on the floatation method. In an underwritten 
Table 6 Discount, floatation method and volatility

\begin{tabular}{|c|c|c|c|}
\hline Variables & (1) & (2) & (3) \\
\hline Discount & $\begin{array}{l}-0.040 * * \\
(0.016)\end{array}$ & $\begin{array}{l}-0.025^{*} \\
(0.013)\end{array}$ & $\begin{array}{l}-0.053 \text { *** } \\
(0.014)\end{array}$ \\
\hline Discount $\times$ Underwritten & & $\begin{array}{l}-0.032 \\
(0.025)\end{array}$ & $\begin{array}{l}-0.022 \\
(0.025)\end{array}$ \\
\hline Discount $\times$ Return STD & & & $\begin{array}{l}0.024 * * \\
(0.010)\end{array}$ \\
\hline Growth & $\begin{array}{l}-0.001 \\
(0.015)\end{array}$ & $\begin{array}{l}-0.002 \\
(0.015)\end{array}$ & $\begin{array}{l}-0.000 \\
(0.015)\end{array}$ \\
\hline OV & $\begin{array}{l}-0.004 \\
(0.002)\end{array}$ & $\begin{array}{l}-0.004 \\
(0.002)\end{array}$ & $\begin{array}{l}-0.004 \\
(0.002)\end{array}$ \\
\hline ROA & $\begin{array}{l}0.045 \\
(0.134)\end{array}$ & $\begin{array}{l}0.043 \\
(0.136)\end{array}$ & $\begin{array}{l}0.049 \\
(0.131)\end{array}$ \\
\hline Debt Repayment & $\begin{array}{l}0.011 \\
(0.011)\end{array}$ & $\begin{array}{l}0.011 \\
(0.011)\end{array}$ & $\begin{array}{l}0.009 \\
(0.010)\end{array}$ \\
\hline New Investment & $\begin{array}{l}-0.031 * * * \\
(0.008)\end{array}$ & $\begin{array}{l}-0.031 * * * \\
(0.008)\end{array}$ & $\begin{array}{l}-0.032 * * * \\
(0.008)\end{array}$ \\
\hline Underwritten & $\begin{array}{l}-0.031 * \\
(0.015)\end{array}$ & $\begin{array}{l}-0.019 \\
(0.014)\end{array}$ & $\begin{array}{l}-0.022 \\
(0.014)\end{array}$ \\
\hline Leverage & $\begin{array}{l}0.020 \\
(0.086)\end{array}$ & $\begin{array}{l}0.019 \\
(0.087)\end{array}$ & $\begin{array}{l}0.020 \\
(0.084)\end{array}$ \\
\hline Relative size & $\begin{array}{l}0.019 \\
(0.027)\end{array}$ & $\begin{array}{l}0.020 \\
(0.027)\end{array}$ & $\begin{array}{l}0.018 \\
(0.026)\end{array}$ \\
\hline Concentration & $\begin{array}{l}0.020 \\
(0.045)\end{array}$ & $\begin{array}{l}0.019 \\
(0.045)\end{array}$ & $\begin{array}{l}0.020 \\
(0.044)\end{array}$ \\
\hline Analysts & $\begin{array}{l}0.007 \\
(0.007)\end{array}$ & $\begin{array}{l}0.007 \\
(0.007)\end{array}$ & $\begin{array}{l}0.009 \\
(0.006)\end{array}$ \\
\hline Return STD & $\begin{array}{l}0.007 \\
(0.005)\end{array}$ & $\begin{array}{l}0.007 \\
(0.005)\end{array}$ & $\begin{array}{l}-0.004 \\
(0.003)\end{array}$ \\
\hline Return LTM & $\begin{array}{l}-0.000^{* *} \\
(0.000)\end{array}$ & $\begin{array}{l}-0.000^{* *} \\
(0.000)\end{array}$ & $\begin{array}{l}-0.000 * \\
(0.000)\end{array}$ \\
\hline Civil & $\begin{array}{l}0.094 * * * \\
(0.023)\end{array}$ & $\begin{array}{l}0.095 * * * \\
(0.022)\end{array}$ & $\begin{array}{l}0.096 * * * \\
(0.022)\end{array}$ \\
\hline Investor protection & $\begin{array}{l}-0.003 \\
(0.004)\end{array}$ & $\begin{array}{l}-0.003 \\
(0.004)\end{array}$ & $\begin{array}{l}-0.004 \\
(0.004)\end{array}$ \\
\hline Legal rights & $\begin{array}{l}0.005 \\
(0.004)\end{array}$ & $\begin{array}{l}0.005 \\
(0.004)\end{array}$ & $\begin{array}{l}0.006 \\
(0.004)\end{array}$ \\
\hline Anti-self-dealing & $\begin{array}{l}0.135 * * * \\
(0.038)\end{array}$ & $\begin{array}{l}0.135 * * * \\
(0.038)\end{array}$ & $\begin{array}{l}0.128 * * * \\
(0.034)\end{array}$ \\
\hline GDP per capita & $\begin{array}{l}-0.001 \\
(0.003)\end{array}$ & $\begin{array}{l}-0.001 \\
(0.003)\end{array}$ & $\begin{array}{l}-0.001 \\
(0.003)\end{array}$ \\
\hline Constant & $\begin{array}{l}-0.329 * * * \\
(0.077)\end{array}$ & $\begin{array}{l}-0.335^{* * *} \\
(0.076)\end{array}$ & $\begin{array}{l}-0.322 * * * \\
(0.076)\end{array}$ \\
\hline Observations & 1.071 & 1.071 & 1.071 \\
\hline
\end{tabular}


Table 6 (continued)

\begin{tabular}{llll}
\hline Variables & $(1)$ & $(2)$ & $(3)$ \\
\hline Adjusted R-squared & 0.033 & 0.033 & 0.039 \\
Prob $>$ F & 0.0000 & 0.0000 & 0.0000 \\
\hline
\end{tabular}

This table presents regression results for our OLS regression with $C A R$ as the dependent variable. Variable definitions can be found in Table 3. Each regression includes year and industry fixed effects. We present robust standard errors clustered on the industry level in parentheses $\left(* * * \mathrm{p}<0.01,{ }^{*} \mathrm{*} \mathrm{p}<0.05, * \mathrm{p}<0.1\right)$

offering, firms do not need to set higher discounts to avoid a failed offer. Hence, a low discount in a non-underwritten offering might send a stronger signal than a low discount in an underwritten offering, as a lower discount might also lead to a higher failure probability in a non-underwritten rights offering. Only high quality firms can bear this increased failure probability. Certainly, this argument does not hold for underwritten offerings since a smaller discount does not lead to a higher failure probability for those insured offers. To analyse this presumption, we include the interaction term Discount $\times$ Underwritten in our regression model, capturing the influence of the discount for underwritten and non-underwritten offerings. Model 2 from Table 6 presents the results. While the coefficient of the interaction term is insignificant, the coefficient of Discount remains negative and significant. This highlights the importance of the discount across underwritten and non-underwritten offerings.

Finally, one might also argue that the importance of the discount depends on the stock return volatility. Firms with especially high stock return volatility might be forced to set higher discounts to secure the offering and vice versa. A high discount could hint either at low firm quality or at higher stock return volatility. Thus, a small discount might send a stronger signal for a firm with a high volatility, compared to a low volatility firm. For this purpose, we include the interaction term Discount $\times$ Return STD as a further variable into our regression model, along with Discount $\times$ Underwritten. The results in Model 3 from Table 6 show that the coefficient of Discount retains its negative and significant sign, while the coefficient of Discount $\times$ Return $S T D$ is significantly positive, which indicates that the discount positively impacts announcement effects for highly volatile stocks. However, across all models, Discount retains its significant and negative coefficient. This highlights the importance and relevance of the discount across different circumstances. Furthermore, the coefficient of Underwritten loses its significance in Model 2 and 3. This strengthens the assumption that the discount is a more relevant signalling instrument than the floatation method in our sample. ${ }^{10}$

\subsection{Robustness checks}

To test the robustness of our results, we employ some additional tests. First, we use a shorter event-window to calculate the cumulated abnormal return. We measure the

$\overline{10}$ We thank an anonymous referee for the suggestion to include this section in the paper. 
Table 7 CAR based on a shorter event window

\begin{tabular}{|c|c|c|c|c|}
\hline Variables & $\begin{array}{l}\text { (1) High Markt } \\
\text { Development }\end{array}$ & $\begin{array}{l}\text { (2) Low Market } \\
\text { Development }\end{array}$ & $\begin{array}{l}\text { (3) High Govern- } \\
\text { ance Rating }\end{array}$ & $\begin{array}{l}\text { (4) Low } \\
\text { Governance } \\
\text { Rating }\end{array}$ \\
\hline Discount & $\begin{array}{l}-0.015 \\
(0.025)\end{array}$ & $\begin{array}{l}-0.074 * * * \\
(0.019)\end{array}$ & $\begin{array}{l}-0.046^{*} \\
(0.021)\end{array}$ & $\begin{array}{l}-0.047^{*} \\
(0.023)\end{array}$ \\
\hline Growth & $\begin{array}{l}0.001 \\
(0.012)\end{array}$ & $\begin{array}{l}0.005 \\
(0.014)\end{array}$ & $\begin{array}{l}0.005 \\
(0.008)\end{array}$ & $\begin{array}{l}-0.008 \\
(0.022)\end{array}$ \\
\hline $\mathrm{OV}$ & $\begin{array}{l}-0.004 \\
(0.003)\end{array}$ & $\begin{array}{l}-0.005 \\
(0.004)\end{array}$ & $\begin{array}{l}-0.002 \\
(0.005)\end{array}$ & $\begin{array}{l}-0.006 \\
(0.004)\end{array}$ \\
\hline ROA & $\begin{array}{l}0.024 \\
(0.105)\end{array}$ & $\begin{array}{l}0.123 \\
(0.097)\end{array}$ & $\begin{array}{l}0.067 \\
(0.087)\end{array}$ & $\begin{array}{l}0.036 \\
(0.115)\end{array}$ \\
\hline Debt repayment & $\begin{array}{l}-0.003 \\
(0.008)\end{array}$ & $\begin{array}{l}-0.001 \\
(0.006)\end{array}$ & $\begin{array}{l}-0.015 \\
(0.015)\end{array}$ & $\begin{array}{l}0.012 \\
(0.011)\end{array}$ \\
\hline New investment & $\begin{array}{l}-0.016 \\
(0.011)\end{array}$ & $\begin{array}{l}-0.015 \\
(0.009)\end{array}$ & $\begin{array}{l}-0.012 \\
(0.018)\end{array}$ & $\begin{array}{l}-0.025^{* *} \\
(0.008)\end{array}$ \\
\hline Underwritten & $\begin{array}{l}-0.023 \\
(0.024)\end{array}$ & $\begin{array}{l}-0.025^{*} \\
(0.011)\end{array}$ & $\begin{array}{l}-0.027 \\
(0.015)\end{array}$ & $\begin{array}{l}-0.011 \\
(0.012)\end{array}$ \\
\hline Leverage & $\begin{array}{l}0.033 \\
(0.088)\end{array}$ & $\begin{array}{l}0.045 \\
(0.058)\end{array}$ & $\begin{array}{l}0.073 \\
(0.062)\end{array}$ & $\begin{array}{l}-0.000 \\
(0.094)\end{array}$ \\
\hline Relative size & $\begin{array}{l}0.022 \\
(0.018)\end{array}$ & $\begin{array}{l}0.041 \\
(0.040)\end{array}$ & $\begin{array}{l}0.054 * * * \\
(0.016)\end{array}$ & $\begin{array}{l}-0.008 \\
(0.034)\end{array}$ \\
\hline Concentration & $\begin{array}{l}0.120 * * \\
(0.045)\end{array}$ & $\begin{array}{l}-0.001 \\
(0.034)\end{array}$ & $\begin{array}{l}0.073 \\
(0.046)\end{array}$ & $\begin{array}{l}0.003 \\
(0.037)\end{array}$ \\
\hline Analysts & $\begin{array}{l}0.018 * * * \\
(0.005)\end{array}$ & $\begin{array}{l}0.005 \\
(0.010)\end{array}$ & $\begin{array}{l}0.008 \\
(0.008)\end{array}$ & $\begin{array}{l}0.009 \\
(0.010)\end{array}$ \\
\hline Return STD & $\begin{array}{l}0.017 * * \\
(0.007)\end{array}$ & $\begin{array}{l}0.003 \\
(0.003)\end{array}$ & $\begin{array}{l}0.011 \\
(0.012)\end{array}$ & $\begin{array}{l}0.006 \\
(0.006)\end{array}$ \\
\hline Return LTM & $\begin{array}{l}0.000 \\
(0.000)\end{array}$ & $\begin{array}{l}-0.000^{* * *} \\
(0.000)\end{array}$ & $\begin{array}{l}-0.000 \\
(0.000)\end{array}$ & $\begin{array}{l}-0.000 \\
(0.000)\end{array}$ \\
\hline Civil & $\begin{array}{l}0.062 \\
(0.057)\end{array}$ & $\begin{array}{l}0.088 * * * \\
(0.014)\end{array}$ & $\begin{array}{l}0.142 \\
(0.178)\end{array}$ & $\begin{array}{l}0.079 * * * \\
(0.007)\end{array}$ \\
\hline Investor protection & $\begin{array}{l}0.007 \\
(0.005)\end{array}$ & $\begin{array}{l}-0.005 \\
(0.007)\end{array}$ & $\begin{array}{l}0.035^{* *} \\
(0.016)\end{array}$ & $\begin{array}{l}-0.005 \\
(0.007)\end{array}$ \\
\hline Legal rights & $\begin{array}{l}0.023 * * \\
(0.008)\end{array}$ & $\begin{array}{l}0.010 * * \\
(0.004)\end{array}$ & $\begin{array}{l}-0.084 \\
(0.075)\end{array}$ & $\begin{array}{l}0.006 \\
(0.004)\end{array}$ \\
\hline Anti-self-dealing & $\begin{array}{l}0.025 \\
(0.130)\end{array}$ & $\begin{array}{l}0.065 \\
(0.035)\end{array}$ & $\begin{array}{l}0.508 \\
(0.643)\end{array}$ & $\begin{array}{l}0.156^{* * * *} \\
(0.045)\end{array}$ \\
\hline GDP per capita & $\begin{array}{l}0.006 \\
(0.008)\end{array}$ & $\begin{array}{l}-0.014 * * \\
(0.004)\end{array}$ & $\begin{array}{l}0.081 \\
(0.054)\end{array}$ & $\begin{array}{l}-0.001 \\
(0.002)\end{array}$ \\
\hline Constant & $\begin{array}{l}-0.729 * * * \\
(0.120)\end{array}$ & $\begin{array}{l}-0.097 \\
(0.074)\end{array}$ & $\begin{array}{l}-0.428 \\
(0.245)\end{array}$ & $\begin{array}{l}-0.244 * * \\
(0.087)\end{array}$ \\
\hline Observations & 499 & 572 & 522 & 462 \\
\hline Adjusted R-squared & 0.034 & 0.041 & 0.019 & 0.057 \\
\hline Prob $>F$ & 0.0000 & 0.0000 & 0.0230 & 0.0000 \\
\hline
\end{tabular}


Table 7 (continued)

This table presents regression results for our OLS regression with CAR from a 7-day event window $[-3 ; 3]$ as the dependent variable. In Model 1 and 2, we split the sample into firm with high (larger than median) and low (smaller or equal to median) values of Market Development. In Model 3 and 4, we split the sample into firm with high (larger than median) and low (smaller or equal to median) values of Governance Rating. Variable definitions can be found in Table 3. Each regression includes year and industry fixed effects. We present robust standard errors clustered on the industry level in parentheses $(* * * \mathrm{p}<0.01, * * \mathrm{p}<0.05, * \mathrm{p}<0.1)$

cumulated abnormal return in Table 7 in a 7-day event window [-3; 3]. Regarding Market Development, the results maintain that the coefficient of Discount loads only significantly in low transparency environments, which is in line with our main results. For Governance Rating, the coefficient of Discount is significant in high and low transparency surroundings, which contradicts our hypothesis. However, the results of Model 3 must be interpreted with caution, as this regression is prone to multicollinearity. ${ }^{11}$

Additionally, we drop all financial firms in a second robustness check in Table 8. The results support our previous findings. Discount remains only significant in low transparency environments for both transparency variables.

Furthermore, one might object that countries with disproportionately many observations could distort our results. With 235 observations in our main regression, Australian firms account for most equity rights offerings in our analyses, representing almost a quarter of our dataset. ${ }^{12}$ Thus, we drop all firms from Australia in a further test in Table 9. As in the previous analyses, Discount is solely significant in low transparency environments.

In a similar vein, we drop all observations from countries with less than five equity rights offerings (i.e. Brazil, Chile, Colombia, Egypt, Greece, Israel, Japan, Lithuania, Luxembourg, Morocco, Nigeria, Pakistan, Philippines, Romania and Sri Lanka) in Table 10 for an additional test, as country-specific effects from countries with few observations could also distort our results. ${ }^{13}$ The results confirm our previous findings, again, Discount is only significant if financial market transparency is low.

Besides excluding certain countries from our regressions to avoid a potential bias by country-specific effects, we perform a further regression and include country fixed effects instead of the country-specific controls. We prefer to explicitly include country-level controls in our main regression, as the previous literature showed that these factors play an important role in explaining announcement effects of equity offerings across countries (Holderness 2018). However, there may exist some country-specific factors which we missed in our analysis, but which explain a large fraction of our dependent variable $(C A R)$. To avoid such a potential distortion of our results due to omitted factors, we perform this additional test. Table 11 presents our

\footnotetext{
${ }^{11}$ Indicated by a mean variance inflation factor of 75.68 .

12 As described above and in Table 3, we lose several observations from our original dataset due to missing variables. Hence, the number of firms from a certain country reported here and included in our regressions does not necessarily match the number of firms in our event study (Table 4).

13 As explained in the previous footnote, these countries might not coincide with the countries from Table 4 with less than five observations.
} 
Table 8 Regression results without financial firms

\begin{tabular}{|c|c|c|c|c|}
\hline Variables & $\begin{array}{l}\text { (1) High Market } \\
\text { Development }\end{array}$ & $\begin{array}{l}\text { (2) Low Market } \\
\text { Development }\end{array}$ & $\begin{array}{l}\text { (3) High Govern- } \\
\text { ance Rating }\end{array}$ & $\begin{array}{l}\text { (4) Low } \\
\text { Governance } \\
\text { Rating }\end{array}$ \\
\hline Discount & $\begin{array}{l}-0.017 \\
(0.032)\end{array}$ & $\begin{array}{l}-0.083 * * \\
(0.028)\end{array}$ & $\begin{array}{l}-0.042 \\
(0.037)\end{array}$ & $\begin{array}{l}-0.050 * * \\
(0.020)\end{array}$ \\
\hline Growth & $\begin{array}{l}0.003 \\
(0.020)\end{array}$ & $\begin{array}{l}-0.002 \\
(0.013)\end{array}$ & $\begin{array}{l}-0.001 \\
(0.014)\end{array}$ & $\begin{array}{l}0.008 \\
(0.020)\end{array}$ \\
\hline OV & $\begin{array}{l}-0.007 * * \\
(0.002)\end{array}$ & $\begin{array}{l}-0.007 \\
(0.006)\end{array}$ & $\begin{array}{l}-0.006^{* *} \\
(0.002)\end{array}$ & $\begin{array}{l}-0.005 \\
(0.006)\end{array}$ \\
\hline ROA & $\begin{array}{l}0.069 \\
(0.146)\end{array}$ & $\begin{array}{l}0.103 \\
(0.120)\end{array}$ & $\begin{array}{l}0.074 \\
(0.120)\end{array}$ & $\begin{array}{l}0.143 \\
(0.127)\end{array}$ \\
\hline Debt repayment & $\begin{array}{l}-0.006 \\
(0.009)\end{array}$ & $\begin{array}{l}0.017 \\
(0.012)\end{array}$ & $\begin{array}{l}-0.011 \\
(0.023)\end{array}$ & $\begin{array}{l}0.016 \\
(0.015)\end{array}$ \\
\hline New investment & $\begin{array}{l}-0.010 \\
(0.015)\end{array}$ & $\begin{array}{l}-0.017 \\
(0.016)\end{array}$ & $\begin{array}{l}-0.004 \\
(0.010)\end{array}$ & $\begin{array}{l}-0.022 \\
(0.014)\end{array}$ \\
\hline Underwritten & $\begin{array}{l}-0.048 \\
(0.032)\end{array}$ & $\begin{array}{l}-0.033^{*} \\
(0.016)\end{array}$ & $\begin{array}{l}-0.048 * * \\
(0.019)\end{array}$ & $\begin{array}{l}-0.021 \\
(0.015)\end{array}$ \\
\hline Leverage & $\begin{array}{l}0.056 \\
(0.100)\end{array}$ & $\begin{array}{l}0.018 \\
(0.055)\end{array}$ & $\begin{array}{l}0.084 \\
(0.098)\end{array}$ & $\begin{array}{l}0.052 \\
(0.082)\end{array}$ \\
\hline Relative Size & $\begin{array}{l}0.038 * \\
(0.018)\end{array}$ & $\begin{array}{l}0.076^{*} \\
(0.040)\end{array}$ & $\begin{array}{l}0.053 * * \\
(0.020)\end{array}$ & $\begin{array}{l}0.027 \\
(0.052)\end{array}$ \\
\hline Concentration & $\begin{array}{l}0.116^{*} \\
(0.058)\end{array}$ & $\begin{array}{l}-0.039 \\
(0.050)\end{array}$ & $\begin{array}{l}0.058 \\
(0.055)\end{array}$ & $\begin{array}{l}-0.013 \\
(0.061)\end{array}$ \\
\hline Analysts & $\begin{array}{l}0.019 * \\
(0.010)\end{array}$ & $\begin{array}{l}0.005 \\
(0.014)\end{array}$ & $\begin{array}{l}0.000 \\
(0.008)\end{array}$ & $\begin{array}{l}0.013 \\
(0.013)\end{array}$ \\
\hline Return STD & $\begin{array}{l}0.022 * * \\
(0.008)\end{array}$ & $\begin{array}{l}0.002 \\
(0.003)\end{array}$ & $\begin{array}{l}0.017 \\
(0.013)\end{array}$ & $\begin{array}{l}0.005 \\
(0.006)\end{array}$ \\
\hline Return LTM & $\begin{array}{l}-0.000 \\
(0.000)\end{array}$ & $\begin{array}{l}-0.000 * * \\
(0.000)\end{array}$ & $\begin{array}{l}-0.000 \\
(0.000)\end{array}$ & $\begin{array}{l}-0.000 \\
(0.000)\end{array}$ \\
\hline Civil & $\begin{array}{l}0.139 * * \\
(0.056)\end{array}$ & $\begin{array}{l}0.120 * * * \\
(0.026)\end{array}$ & $\begin{array}{l}-0.272 * \\
(0.132)\end{array}$ & $\begin{array}{l}0.119 * * * \\
(0.027)\end{array}$ \\
\hline Investor protection & $\begin{array}{l}0.007 \\
(0.010)\end{array}$ & $\begin{array}{l}-0.013 \\
(0.007)\end{array}$ & $\begin{array}{l}-0.012 \\
(0.014)\end{array}$ & $\begin{array}{l}-0.007 \\
(0.004)\end{array}$ \\
\hline Legal rights & $\begin{array}{l}0.024 \\
(0.015)\end{array}$ & $\begin{array}{l}0.015 * * \\
(0.005)\end{array}$ & $\begin{array}{l}0.107 * \\
(0.057)\end{array}$ & $\begin{array}{l}0.013 * * \\
(0.005)\end{array}$ \\
\hline Anti-self-dealing & $\begin{array}{l}0.177 \\
(0.140)\end{array}$ & $\begin{array}{l}0.099 * * \\
(0.036)\end{array}$ & $\begin{array}{l}-1.026^{*} \\
(0.481)\end{array}$ & $\begin{array}{l}0.222 * * * \\
(0.045)\end{array}$ \\
\hline GDP per capita & $\begin{array}{l}0.003 \\
(0.007)\end{array}$ & $\begin{array}{l}-0.016^{* *} \\
(0.007)\end{array}$ & $\begin{array}{l}-0.062 \\
(0.043)\end{array}$ & $\begin{array}{l}-0.001 \\
(0.004)\end{array}$ \\
\hline Constant & $\begin{array}{l}-0.817 \text { *** } \\
(0.191)\end{array}$ & $\begin{array}{l}-0.130^{*} \\
(0.058)\end{array}$ & $\begin{array}{l}0.010 \\
(0.240)\end{array}$ & $\begin{array}{l}-0.508 * * * \\
(0.112)\end{array}$ \\
\hline Observations & 453 & 486 & 468 & 394 \\
\hline Adjusted R-squared & 0.068 & 0.077 & 0.042 & 0.077 \\
\hline Prob $>F$ & 0.0000 & 0.0000 & 0.0000 & 0.0000 \\
\hline
\end{tabular}


Table 8 (continued)

This table presents regression results for our OLS regression with $C A R$ as the dependent variable. In these regressions, we dropped all financial firms. In Model 1 and 2, we split the sample into firm with high (larger than median) and low (smaller or equal to median) values of Market Development. In Model 3 and 4, we split the sample into firm with high (larger than median) and low (smaller or equal to median) values of Governance Rating. Variable definitions can be found in Table 3. Each regression includes year and industry fixed effects. We present robust standard errors clustered on the industry level in parentheses $(* * * \mathrm{p}<0.01, * * \mathrm{p}<0.05, * \mathrm{p}<0.1)$

results using country fixed effects instead. Our findings that Discount is only relevant in low transparency environments substantiate.

\section{Conclusion}

In this study, we analyse the announcement effects of equity rights offerings worldwide. In line with previous studies, we show that announcement effects of equity rights offerings vary across different countries. Although the average effect across all countries worldwide is significantly negative, we still observe on average positive announcement effects for several countries. Besides measuring these announcement effects, our study focuses on assessing the relevance of the discount in different transparency environments. Previous theoretical and empirical literature showed that the discount should generally affect the announcement effect of an equity rights offering. For instance, firms can signal their true quality to the (uninformed) shareholders. Building on that, we thus argue and show that the discount is only relevant in environments where signalling is possible and necessary. We posit that this is the case in financial markets where the information asymmetry between shareholders and management is high. In our study, we focus on country-level measures for financial market transparency and thus information asymmetry. We use two proxies for the level of financial market transparency on a country level and argue that higher market transparency should lead to lower information asymmetry.

Our results show that the negative effect of the discount on announcement effects indeed only appears in environments with a low transparency and thus high information asymmetry. These effects substantiate if we drop financial firms, measure the announcement effects in a smaller event window, drop all observations from the country with the most offerings or from countries with especially few offerings or include country fixed effects.

Our analysis shows that the share price reacts particularly sensitive to the discount of an equity rights issue in countries with ceteris paribus higher information asymmetry. Thus, firms face a certain trade-off between a higher subscription price and a lower failure risk. On the one side, in order to avoid negative announcement effects, firms should set the subscription price as high as possible and thus minimize the discount. On the other side, firms might, however, not be able to maximize 
Table 9 Regression results without firms from Australia

\begin{tabular}{|c|c|c|c|c|}
\hline Variables & $\begin{array}{l}\text { (1) High Market } \\
\text { Development }\end{array}$ & $\begin{array}{l}\text { (2) Low Market } \\
\text { Development }\end{array}$ & $\begin{array}{l}\text { (3) High Govern- } \\
\text { ance Rating }\end{array}$ & $\begin{array}{l}\text { (4) Low } \\
\text { Governance } \\
\text { Rating }\end{array}$ \\
\hline Discount & $\begin{array}{l}-0.012 \\
(0.077)\end{array}$ & $\begin{array}{l}-0.084 * * * \\
(0.024)\end{array}$ & $\begin{array}{l}-0.081 \\
(0.047)\end{array}$ & $\begin{array}{l}-0.082 * * \\
(0.027)\end{array}$ \\
\hline Growth & $\begin{array}{l}-0.033 \\
(0.031)\end{array}$ & $\begin{array}{l}0.005 \\
(0.015)\end{array}$ & $\begin{array}{l}-0.033 * * \\
(0.013)\end{array}$ & $\begin{array}{l}0.002 \\
(0.035)\end{array}$ \\
\hline $\mathrm{OV}$ & $\begin{array}{l}-0.014 * * \\
(0.005)\end{array}$ & $\begin{array}{l}-0.008^{*} \\
(0.004)\end{array}$ & $\begin{array}{l}-0.029 * * * \\
(0.004)\end{array}$ & $\begin{array}{l}-0.003 \\
(0.005)\end{array}$ \\
\hline ROA & $\begin{array}{l}-0.103 \\
(0.186)\end{array}$ & $\begin{array}{l}0.091 \\
(0.094)\end{array}$ & $\begin{array}{l}-0.024 \\
(0.167)\end{array}$ & $\begin{array}{l}0.063 \\
(0.227)\end{array}$ \\
\hline Debt repayment & $\begin{array}{l}-0.003 \\
(0.017)\end{array}$ & $\begin{array}{l}0.016 \\
(0.010)\end{array}$ & $\begin{array}{l}-0.005 \\
(0.023)\end{array}$ & $\begin{array}{l}0.028 * \\
(0.014)\end{array}$ \\
\hline New Investment & $\begin{array}{l}-0.005 \\
(0.029)\end{array}$ & $\begin{array}{l}-0.033^{*} \\
(0.016)\end{array}$ & $\begin{array}{l}-0.014 \\
(0.028)\end{array}$ & $\begin{array}{l}-0.019 \\
(0.012)\end{array}$ \\
\hline Underwritten & $\begin{array}{l}-0.009 \\
(0.029)\end{array}$ & $\begin{array}{l}-0.027 \\
(0.018)\end{array}$ & $\begin{array}{l}-0.023 \\
(0.019)\end{array}$ & $\begin{array}{l}-0.019 \\
(0.019)\end{array}$ \\
\hline Leverage & $\begin{array}{l}-0.067 \\
(0.141)\end{array}$ & $\begin{array}{l}0.046 \\
(0.065)\end{array}$ & $\begin{array}{l}0.050 \\
(0.093)\end{array}$ & $\begin{array}{l}-0.024 \\
(0.124)\end{array}$ \\
\hline Relative size & $\begin{array}{l}0.040 \\
(0.031)\end{array}$ & $\begin{array}{l}0.041 \\
(0.048)\end{array}$ & $\begin{array}{l}0.062 \\
(0.037)\end{array}$ & $\begin{array}{l}0.002 \\
(0.053)\end{array}$ \\
\hline Concentration & $\begin{array}{l}0.011 \\
(0.064)\end{array}$ & $\begin{array}{l}-0.013 \\
(0.046)\end{array}$ & $\begin{array}{l}-0.038 \\
(0.040)\end{array}$ & $\begin{array}{l}0.009 \\
(0.045)\end{array}$ \\
\hline Analysts & $\begin{array}{l}0.026 * * \\
(0.011)\end{array}$ & $\begin{array}{l}0.003 \\
(0.012)\end{array}$ & $\begin{array}{l}0.008 \\
(0.011)\end{array}$ & $\begin{array}{l}0.003 \\
(0.011)\end{array}$ \\
\hline Return STD & $\begin{array}{l}0.017 * \\
(0.008)\end{array}$ & $\begin{array}{l}0.004 \\
(0.002)\end{array}$ & $\begin{array}{l}0.018^{*} \\
(0.008)\end{array}$ & $\begin{array}{l}0.002 \\
(0.002)\end{array}$ \\
\hline Return LTM & $\begin{array}{l}-0.000 \\
(0.000)\end{array}$ & $\begin{array}{l}-0.000 * * * \\
(0.000)\end{array}$ & $\begin{array}{l}-0.000 \\
(0.000)\end{array}$ & $\begin{array}{l}-0.000^{*} \\
(0.000)\end{array}$ \\
\hline Civil & $\begin{array}{l}0.086 \\
(0.090)\end{array}$ & $\begin{array}{l}0.117 * * * \\
(0.027)\end{array}$ & $\begin{array}{l}0.027 \\
(0.080)\end{array}$ & $\begin{array}{l}0.123 * * * \\
(0.026)\end{array}$ \\
\hline Investor protection & $\begin{array}{l}0.018^{*} \\
(0.010)\end{array}$ & $\begin{array}{l}-0.009 \\
(0.008)\end{array}$ & $\begin{array}{l}0.057 * \\
(0.025)\end{array}$ & $\begin{array}{l}-0.020^{* * *} \\
(0.005)\end{array}$ \\
\hline Legal rights & $\begin{array}{l}0.025 \\
(0.027)\end{array}$ & $\begin{array}{l}0.011 * * \\
(0.005)\end{array}$ & $\begin{array}{l}0.003 \\
(0.010)\end{array}$ & $\begin{array}{l}0.020 * * \\
(0.008)\end{array}$ \\
\hline Anti-self-dealing & $\begin{array}{l}0.038 \\
(0.199)\end{array}$ & $\begin{array}{l}0.129 * * * \\
(0.027)\end{array}$ & $\begin{array}{l}-0.228 \\
(0.188)\end{array}$ & $\begin{array}{l}0.222 * * * \\
(0.051)\end{array}$ \\
\hline GDP per capita & $\begin{array}{l}0.010 \\
(0.009)\end{array}$ & $\begin{array}{l}-0.015^{*} \\
(0.007)\end{array}$ & $\begin{array}{l}-0.003 \\
(0.012)\end{array}$ & $\begin{array}{l}-0.008 \\
(0.008)\end{array}$ \\
\hline Constant & $\begin{array}{l}-0.713^{*} \\
(0.377)\end{array}$ & $\begin{array}{l}-0.185^{* *} \\
(0.074)\end{array}$ & $\begin{array}{l}-0.318^{*} \\
(0.170)\end{array}$ & $\begin{array}{l}-0.379^{*} \\
(0.181)\end{array}$ \\
\hline Observations & 263 & 572 & 386 & 362 \\
\hline Adjusted R-squared & 0.033 & 0.042 & 0.054 & 0.076 \\
\hline Prob $>F$ & 0.1168 & 0.0000 & 0.0000 & 0.0000 \\
\hline
\end{tabular}


Table 9 (continued)

This table presents regression results for our OLS regression with $C A R$ as the dependent variable. In these regressions, we dropped all firms from Australia. In Model 1 and 2, we split the sample into firm with high (larger than median) and low (smaller or equal to median) values of Market Development. In Model 3 and 4, we split the sample into firm with high (larger than median) and low (smaller or equal to median) values of Governance Rating. Variable definitions can be found in Table 3. Each regression includes year and industry fixed effects. We present robust standard errors clustered on the industry level in parentheses $(* * * \mathrm{p}<0.01, * * \mathrm{p}<0.05, * \mathrm{p}<0.1)$

Table 10 Regression results without countries with less than five offerings

\begin{tabular}{|c|c|c|c|c|}
\hline Variables & $\begin{array}{l}\text { (1) High Market } \\
\text { Development }\end{array}$ & $\begin{array}{l}\text { (2) Low Market } \\
\text { Development }\end{array}$ & $\begin{array}{l}\text { (3) High Govern- } \\
\text { ance Rating }\end{array}$ & $\begin{array}{l}\text { (4) Low } \\
\text { Governance } \\
\text { Rating }\end{array}$ \\
\hline Discount & $\begin{array}{l}-0.018 \\
(0.033)\end{array}$ & $\begin{array}{l}-0.096 * * * \\
(0.023)\end{array}$ & $\begin{array}{l}-0.049 \\
(0.036)\end{array}$ & $\begin{array}{l}-0.063 * \\
(0.030)\end{array}$ \\
\hline Growth & $\begin{array}{l}-0.004 \\
(0.020)\end{array}$ & $\begin{array}{l}-0.001 \\
(0.014)\end{array}$ & $\begin{array}{l}-0.001 \\
(0.015)\end{array}$ & $\begin{array}{l}-0.007 \\
(0.030)\end{array}$ \\
\hline $\mathrm{OV}$ & $\begin{array}{l}-0.006^{*} \\
(0.003)\end{array}$ & $\begin{array}{l}-0.010 \\
(0.006)\end{array}$ & $\begin{array}{l}-0.006^{* *} \\
(0.003)\end{array}$ & $\begin{array}{l}-0.008 \\
(0.006)\end{array}$ \\
\hline ROA & $\begin{array}{l}0.019 \\
(0.152)\end{array}$ & $\begin{array}{l}0.064 \\
(0.127)\end{array}$ & $\begin{array}{l}0.053 \\
(0.127)\end{array}$ & $\begin{array}{l}0.048 \\
(0.185)\end{array}$ \\
\hline Debt repayment & $\begin{array}{l}0.004 \\
(0.012)\end{array}$ & $\begin{array}{l}0.014 \\
(0.013)\end{array}$ & $\begin{array}{l}-0.002 \\
(0.021)\end{array}$ & $\begin{array}{l}0.022 \\
(0.012)\end{array}$ \\
\hline New Investment & $\begin{array}{l}-0.009 \\
(0.013)\end{array}$ & $\begin{array}{l}-0.032 * \\
(0.016)\end{array}$ & $\begin{array}{l}-0.025 \\
(0.021)\end{array}$ & $\begin{array}{l}-0.019 \\
(0.012)\end{array}$ \\
\hline Underwritten & $\begin{array}{l}-0.038 \\
(0.027)\end{array}$ & $\begin{array}{l}-0.028 \\
(0.018)\end{array}$ & $\begin{array}{l}-0.043^{*} \\
(0.020)\end{array}$ & $\begin{array}{l}-0.017 \\
(0.014)\end{array}$ \\
\hline Leverage & $\begin{array}{l}0.016 \\
(0.108)\end{array}$ & $\begin{array}{l}0.026 \\
(0.058)\end{array}$ & $\begin{array}{l}0.066 \\
(0.088)\end{array}$ & $\begin{array}{l}-0.002 \\
(0.125)\end{array}$ \\
\hline Relative size & $\begin{array}{l}0.016 \\
(0.025)\end{array}$ & $\begin{array}{l}0.041 \\
(0.048)\end{array}$ & $\begin{array}{l}0.050 * \\
(0.023)\end{array}$ & $\begin{array}{l}-0.011 \\
(0.046)\end{array}$ \\
\hline Concentration & $\begin{array}{l}0.110^{*} \\
(0.054)\end{array}$ & $\begin{array}{l}-0.013 \\
(0.049)\end{array}$ & $\begin{array}{l}0.058 \\
(0.047)\end{array}$ & $\begin{array}{l}-0.001 \\
(0.051)\end{array}$ \\
\hline Analysts & $\begin{array}{l}0.019 * * \\
(0.008)\end{array}$ & $\begin{array}{l}0.004 \\
(0.013)\end{array}$ & $\begin{array}{l}0.005 \\
(0.008)\end{array}$ & $\begin{array}{l}0.012 \\
(0.011)\end{array}$ \\
\hline Return STD & $\begin{array}{l}0.018 * * \\
(0.007)\end{array}$ & $\begin{array}{l}0.003 \\
(0.003)\end{array}$ & $\begin{array}{l}0.010 \\
(0.013)\end{array}$ & $\begin{array}{l}0.006 \\
(0.005)\end{array}$ \\
\hline Return LTM & $\begin{array}{l}-0.000 \\
(0.000)\end{array}$ & $\begin{array}{l}-0.000 * * * \\
(0.000)\end{array}$ & $\begin{array}{l}-0.000 \\
(0.000)\end{array}$ & $\begin{array}{l}-0.000 * \\
(0.000)\end{array}$ \\
\hline Civil & $\begin{array}{l}0.082 \\
(0.073)\end{array}$ & $\begin{array}{l}0.128 * * * \\
(0.027)\end{array}$ & $\begin{array}{l}-0.069 \\
(0.219)\end{array}$ & $\begin{array}{l}0.123 * * * \\
(0.028)\end{array}$ \\
\hline Investor protection & $\begin{array}{l}0.007 \\
(0.007)\end{array}$ & $\begin{array}{l}-0.004 \\
(0.010)\end{array}$ & $\begin{array}{l}0.016 \\
(0.024)\end{array}$ & $\begin{array}{l}-0.004 \\
(0.004)\end{array}$ \\
\hline Legal rights & $\begin{array}{l}0.021 \\
(0.014)\end{array}$ & $\begin{array}{l}0.013 * * * \\
(0.003)\end{array}$ & $\begin{array}{l}-0.021 \\
(0.098)\end{array}$ & $\begin{array}{l}0.009 \\
(0.006)\end{array}$ \\
\hline
\end{tabular}


Table 10 (continued)

\begin{tabular}{lllll}
\hline Variables & $\begin{array}{l}\text { (1) High Market } \\
\text { Development }\end{array}$ & $\begin{array}{l}\text { (2) Low Market } \\
\text { Development }\end{array}$ & $\begin{array}{l}\text { (3) High Govern- } \\
\text { ance Rating }\end{array}$ & $\begin{array}{l}\text { (4) Low } \\
\text { Governance } \\
\text { Rating }\end{array}$ \\
\hline Anti-self-dealing & 0.068 & $0.100^{* *}$ & -0.131 & $0.192^{* * *}$ \\
GDP per capita & $(0.155)$ & $(0.036)$ & $(0.807)$ & $(0.030)$ \\
& 0.006 & $-0.020^{* *}$ & 0.018 & -0.003 \\
Constant & $(0.009)$ & $(0.008)$ & $(0.074)$ & $(0.003)$ \\
& $-0.684^{* *}$ & -0.182 & -0.084 & $-0.422^{* *}$ \\
Observations & $(0.215)$ & $(0.103)$ & $(0.303)$ & $(0.161)$ \\
Adjusted R-squared & 497 & 548 & 519 & 450 \\
Prob $>$ F & 0.041 & 0.027 & 0.025 & 0.029 \\
\hline
\end{tabular}

This table presents regression results for our OLS regression with CAR as the dependent variable. In these regressions, we dropped all firms from countries with less than five equity rights offerings (Brazil, Chile, Colombia, Egypt, Greece, Israel, Japan, Lithuania, Luxembourg, Morocco, Nigeria, Pakistan, Philippines, Romania and Sri Lanka). In Model 1 and 2, we split the sample into firm with high (larger than median) and low (smaller or equal to median) values of Market Development. In Model 3 and 4 , we split the sample into firm with high (larger than median) and low (smaller or equal to median) values of Governance Rating. Variable definitions can be found in Table 3. Each regression includes year and industry fixed effects. We present robust standard errors clustered on the industry level in parentheses $(* * * \mathrm{p}<0.01, * * \mathrm{p}<0.05, * \mathrm{p}<0.1)$

the subscription price, as they also need to consider the failure risk of the offering, which generally increases with a higher subscription price. Although a complete solution of this problem is beyond the scope of our analysis, our study shows that signalling via the discount only works in environments with ceteris paribus higher information asymmetry. 
Table 11 Regression with country fixed effects

\begin{tabular}{|c|c|c|c|c|}
\hline Variables & $\begin{array}{l}\text { (1) High Market } \\
\text { Development }\end{array}$ & $\begin{array}{l}\text { (2) Low Market } \\
\text { Development }\end{array}$ & $\begin{array}{l}\text { (3) High Govern- } \\
\text { ance Rating }\end{array}$ & $\begin{array}{l}\text { (4) Low } \\
\text { Governance } \\
\text { Rating }\end{array}$ \\
\hline Discount & $\begin{array}{l}-0.016 \\
(0.033)\end{array}$ & $\begin{array}{l}-0.095^{* * *} \\
(0.024)\end{array}$ & $\begin{array}{l}-0.050 \\
(0.035)\end{array}$ & $\begin{array}{l}-0.072 * \\
(0.036)\end{array}$ \\
\hline Growth & $\begin{array}{l}-0.005 \\
(0.020)\end{array}$ & $\begin{array}{l}-0.003 \\
(0.015)\end{array}$ & $\begin{array}{l}-0.001 \\
(0.015)\end{array}$ & $\begin{array}{l}-0.015 \\
(0.025)\end{array}$ \\
\hline OV & $\begin{array}{l}-0.007^{*} \\
(0.003)\end{array}$ & $\begin{array}{l}-0.012 * \\
(0.006)\end{array}$ & $\begin{array}{l}-0.006^{* *} \\
(0.003)\end{array}$ & $\begin{array}{l}-0.011^{*} \\
(0.005)\end{array}$ \\
\hline ROA & $\begin{array}{l}0.016 \\
(0.149)\end{array}$ & $\begin{array}{l}0.064 \\
(0.107)\end{array}$ & $\begin{array}{l}0.057 \\
(0.127)\end{array}$ & $\begin{array}{l}0.016 \\
(0.153)\end{array}$ \\
\hline Debt repayment & $\begin{array}{l}0.004 \\
(0.012)\end{array}$ & $\begin{array}{l}0.002 \\
(0.009)\end{array}$ & $\begin{array}{l}-0.004 \\
(0.021)\end{array}$ & $\begin{array}{l}0.013 \\
(0.012)\end{array}$ \\
\hline New investment & $\begin{array}{l}-0.007 \\
(0.013)\end{array}$ & $\begin{array}{l}-0.032^{*} \\
(0.017)\end{array}$ & $\begin{array}{l}-0.026 \\
(0.021)\end{array}$ & $\begin{array}{l}-0.016 \\
(0.013)\end{array}$ \\
\hline Underwritten & $\begin{array}{l}-0.039 \\
(0.030)\end{array}$ & $\begin{array}{l}-0.026 \\
(0.022)\end{array}$ & $\begin{array}{l}-0.044^{* *} \\
(0.020)\end{array}$ & $\begin{array}{l}-0.013 \\
(0.013)\end{array}$ \\
\hline Leverage & $\begin{array}{l}0.019 \\
(0.106)\end{array}$ & $\begin{array}{l}0.040 \\
(0.064)\end{array}$ & $\begin{array}{l}0.061 \\
(0.090)\end{array}$ & $\begin{array}{l}-0.010 \\
(0.112)\end{array}$ \\
\hline Relative size & $\begin{array}{l}0.014 \\
(0.026)\end{array}$ & $\begin{array}{l}0.040 \\
(0.045)\end{array}$ & $\begin{array}{l}0.050 * \\
(0.023)\end{array}$ & $\begin{array}{l}-0.014 \\
(0.044)\end{array}$ \\
\hline Concentration & $\begin{array}{l}0.111 * \\
(0.054)\end{array}$ & $\begin{array}{l}-0.026 \\
(0.052)\end{array}$ & $\begin{array}{l}0.059 \\
(0.048)\end{array}$ & $\begin{array}{l}-0.024 \\
(0.068)\end{array}$ \\
\hline Analysts & $\begin{array}{l}0.019 * * \\
(0.008)\end{array}$ & $\begin{array}{l}0.003 \\
(0.011)\end{array}$ & $\begin{array}{l}0.003 \\
(0.009)\end{array}$ & $\begin{array}{l}0.009 \\
(0.011)\end{array}$ \\
\hline Return STD & $\begin{array}{l}0.018^{*} \\
(0.009)\end{array}$ & $\begin{array}{l}0.008 * * * \\
(0.002)\end{array}$ & $\begin{array}{l}0.013 \\
(0.013)\end{array}$ & $\begin{array}{l}0.011 * * \\
(0.004)\end{array}$ \\
\hline Return LTM & $\begin{array}{l}-0.000 \\
(0.000)\end{array}$ & $\begin{array}{l}-0.000 * * * \\
(0.000)\end{array}$ & $\begin{array}{l}-0.000 \\
(0.000)\end{array}$ & $\begin{array}{l}-0.000^{*} \\
(0.000)\end{array}$ \\
\hline Constant & $\begin{array}{l}-0.368^{* * *} \\
(0.105)\end{array}$ & $\begin{array}{l}-0.028 \\
(0.095)\end{array}$ & $\begin{array}{l}-0.202 * * * \\
(0.046)\end{array}$ & $\begin{array}{l}-0.259 \\
(0.160)\end{array}$ \\
\hline Observations & 499 & 586 & 522 & 462 \\
\hline Adjusted R-squared & 0.032 & 0.038 & 0.027 & 0.062 \\
\hline Prob $>F$ & 0.0000 & 0.0001 & 0.0000 & 0.0000 \\
\hline
\end{tabular}

This table presents regression results for our OLS regression with $C A R$ as the dependent variable. In Model 1 and 2, we split the sample into firm with high (larger than median) and low (smaller or equal to median) values of Market Development. In Model 3 and 4, we split the sample into firm with high (larger than median) and low (smaller or equal to median) values of Governance Rating. Variable definitions can be found in Table 3. Each regression includes year, industry and country fixed effects. We present robust standard errors clustered on the industry level in parentheses $(* * * p<0.01, * * p<0.05, * p<0.1)$ 
Funding Open Access funding enabled and organized by Projekt DEAL.

Open Access This article is licensed under a Creative Commons Attribution 4.0 International License, which permits use, sharing, adaptation, distribution and reproduction in any medium or format, as long as you give appropriate credit to the original author(s) and the source, provide a link to the Creative Commons licence, and indicate if changes were made. The images or other third party material in this article are included in the article's Creative Commons licence, unless indicated otherwise in a credit line to the material. If material is not included in the article's Creative Commons licence and your intended use is not permitted by statutory regulation or exceeds the permitted use, you will need to obtain permission directly from the copyright holder. To view a copy of this licence, visit http://creativecommons.org/licenses/by/4.0/.

\section{References}

Baker M, Wurgler J (2002) Market timing and capital structure. J Financ 57(1):1-32

Balachandran B, Faff R, Theobald M, van Zijl T (2012) Rights offerings, subscription period, shareholder takeup, and liquidity. J Financ Quant Anal 47(1):213-239

Bobenhausen N, Breuer W, Salzmann A (2020) Determinants of discounts in equity rights issues: an international comparison. Rev Finan Econ 38(2):300-320

Bøhren $\varnothing$, Eckbo BE, Michalsen D (1997) Why underwrite rights offerings? Some new evidence. J Financ Econ 46:223-261

Campello M, Graham JR (2013) Do stock prices influence corporate decisions? Evidence from the technology bubble. J Financ Econ 107:89-110

Djankov S, La Porta R, Lopez-de-Silanes F, Shleifer A (2008) The law and economics of self-dealing. J Financ Econ 88(3):430-465

Doidge C, Karolyi A, Stulz RM (2007) Why do countries matter so much for corporate governance? J Financ Econ 86:1-39

Eckbo BE, Masulis RW (1992) Adverse selection and the rights offer paradox. J Financ Econ 32:293-332

Fan JPH, Titman S, Twite G (2012) An international comparison of capital structure and debt maturity choices. J Financ Quant Anal 47(1):23-56

Francis BB, Hasan I, Lothian JR, Sun X (2010) The signalling hypothesis revisited: evidence from foreign IPOs. J Financ Quant Anal 45(1):81-106

Gebhardt G, Heiden S, Daske H (2001) Determinants of capital market reactions to seasoned equity offers by German corporations, Working Paper Series: Finance and Accounting, No. 85.

Heinkel R, Schwartz ES (1986) Rights versus underwritten offerings: an asymmetric information approach. J Financ 41(1):1-18

Holderness CG (2018) Equity issuances and agency costs: the telling story of shareholder approval around the world. J Financ Econ 129:415-439

Holderness CG, Pontiff J (2016) Shareholder nonparticipation in valuable rights offerings: new findings for an old puzzle. J Financ Econ 120:252-268

Kabir R, Roosenboom P (2003) Can the stock market anticipate future operating performance? Evidence from equity rights issues. J Corp Financ 9:93-113

La Porta R, Lopez-de-Silanes F, Shleifer A (2008) The economic consequences of legal origins. J Econ Lit 46(2):285-332

MacKinlay AC (1997) Event studies in economics and finance. J Econ Lit 35:13-39

Modigliani F, Miller MH (1958) The cost of capital, corporation finance and the theory of investment. Am Econ Rev 48(3):261-297

Myers SC, Majluf NS (1984) Corporate financing and investment decisions when firms have information that investors do not have. J Financ Econ 13:187-221

Singh AK (1997) Layoffs and underwritten rights offers. J Financ Econ 43:105-130

Slovin MB, Sushka ME, Lai KWL (2000) Alternative flotation methods, adverse selection, and ownership structure: evidence from seasoned equity issuance in the U.K. J Financ Econ 57:157-190

Publisher's Note Springer Nature remains neutral with regard to jurisdictional claims in published maps and institutional affiliations. 